\title{
Experimental Hyperthyroidism Decreases Gene Expression and Serum Levels of Adipokines in Obesity
}

\author{
Renata de Azevedo Melo Luvizotto, ${ }^{1}$ André Ferreira do Nascimento, ${ }^{1}$ \\ Maria Teresa de Síbio, ${ }^{1}$ Regiane Marques Castro Olímpio, ${ }^{1}$ Sandro José Conde, ${ }^{1}$ \\ Ana Paula Lima-Leopoldo, ${ }^{2}$ André Soares Leopoldo, ${ }^{1,2}$ Antonio Carlos Cicogna, ${ }^{1}$ \\ and Célia Regina Nogueira ${ }^{1}$

\begin{abstract}
${ }^{1}$ Department of Internal Medicine, Botucatu School of Medicine, University of São Paulo State, 18618-000 Botucatu, SP, Brazil
${ }^{2}$ Department of Sports, Center of Physical Education and Sports, Federal University of Espirito Santo (UFES),
\end{abstract} \\ 29075-910 Vitória, ES, Brazil
}

Correspondence should be addressed to Renata de Azevedo Melo Luvizotto, reluvizotto@yahoo.com

Received 29 October 2011; Accepted 27 December 2011

Academic Editors: S. Bernasconi, R. E. Felberbaum, and A. Ferlin

Copyright ( 2012 Renata de Azevedo Melo Luvizotto et al. This is an open access article distributed under the Creative Commons Attribution License, which permits unrestricted use, distribution, and reproduction in any medium, provided the original work is properly cited.

\begin{abstract}
Aims. To analyze the influence of hyperthyroidism on the gene expression and serum concentration of leptin, resistin, and adiponectin in obese animals. Main Methods. Male Wistar rats were randomly divided into two groups: control (C)-fed with commercial chow ad libitum — and obese $(\mathrm{OB})$ — fed with a hypercaloric diet. After group characterization, the OB rats continued receiving a hypercaloric diet and were randomized into two groups: obese animals (OB) and obese with $25 \mu \mathrm{g}$ triiodothyronine $\left(\mathrm{T}_{3}\right) / 100 \mathrm{BW}(\mathrm{OT})$. The $\mathrm{T}_{3}$ dose was administered every day for the last 2 weeks of the study. After 30 weeks the animals were euthanized. Samples of blood and adipose tissue were collected for biochemical and hormonal analyses as well as gene expression of leptin, resistin, and adiponectin. Results. $\mathrm{T}_{3}$ treatment was effective, increasing $\mathrm{fT}_{3}$ levels and decreasing $\mathrm{fT}_{4}$ and $\mathrm{TSH}_{\mathrm{H}}$ serum concentration. Administration of $\mathrm{T}_{3}$ promotes weight loss, decreases all fat deposits, and diminishes serum levels of leptin, resistin, and adiponectin by reducing their gene expression. Conclusions. Our results suggest that $\mathrm{T}_{3}$ modulate serum and gene expression levels of leptin, resistin, and adiponectin in experimental model of obesity, providing new insights regarding the relationship between $\mathrm{T}_{3}$ and adipokines in obesity.
\end{abstract}

\section{Introduction}

The thyroid hormones influence energetic metabolism [1] and perform a central role in the regulation of adipose tissue metabolism [2]. Disturbances of these hormones are associated with alterations of body weight and energy expenditure [3]. While it is well known that hyperthyroidism leads to weight loss and hypothyroidism is associated with weight gain, the changes of thyroid function are discussed controversially in obesity [4].

Obesity, a public health problem associated with innumerable incapacitating and chronic diseases [5], is defined as an excessive or abnormal accumulation of adipose tissue that can be detrimental to health [6]. The adipose tissue, previously considered to be the largest, although inert, energy store in the body, actively produces a variety of biological substances. These substances are denominated adipokines and can influence the function and structural integrity of other tissues $[7,8]$. In obesity, the release of adipokines such as leptin, resistin, and adiponectin can be altered [9]. Leptin acts as a signal of satiety in the hypothalamus and thus controls the body weight not only by diminishing the ingestion of foods but also by increasing energetic expenditure [10]. The levels of leptin in the circulatory system are elevated after meals; this increase is due to direct stimulation of expression of the $o b$ gene and/or secretion of leptin from adipose tissue by glucose and insulin [11]. Resistin is secreted by monocytes and adipocytes, and present proinflammatory properties such as TNF- $\alpha$ and IL-6 [12]. Despite being expressed and secreted in thin individuals, elevated levels are associated 
with obesity both in humans and in experimental animal models [13]. However, the detailed functions of resistin are still not understood; it has been appreciated that resistin can cause hepatic insulin resistance and that it may, along with its closely related homologs, interact with immune cells as well [14]. Adiponectin is expressed exclusively in differentiated adipocytes [15], regulates lipid and glucose metabolism, suppresses gluconeogenesis, increases insulin sensitivity, stimulates fatty acid oxidation, protects against chronic inflammation, and regulates food intake and body weight [16]. Its reduction is associated with a decrease in lipid oxidation, increased triglycerides, and a suppression of insulin-dependent signaling in the liver and muscle, all of which can contribute to insulin resistance and obesity [17].

Thyroid hormones are involved in the regulation of adipose tissue whereas the hormones produced by adipose tissue such as resistin, adiponectin, and leptin are involved in regulation of the energetic balance [18]; however, the relationship between these hormones in obesity is controversial and scarcely addressed. In this context, our objective in this study was to analyze the influence of supraphysiological dose of $\mathrm{T}_{3}$ on the gene expression and serum concentration of leptin, resistin, and adiponectin in obese animals.

\section{Materials and Methods}

2.1. Animals and Experimental Protocol. This study utilized male Wistar rats, weighing approximately $150 \mathrm{~g}$, supplied by the Animal Center of the Experimental Laboratory for Clinical Medicine at the "Júlio de Mesquita Filho" Paulista State University in Botucatu, Sao Paulo, Brazil. The animals were initially divided into two groups: control (C) — fed with commercial chow ad libitum-and obese (OB) — fed with a hypercaloric diet, as previously described [19], in order to induce obesity. After the obesity induction, the $\mathrm{OB}$ animals were randomized into two groups: obese animals (OB, $n=$ $10)$, and obese animals administered a supraphysiological dose of $\mathrm{T}_{3}(\mathrm{OT}, n=10)$ at a concentration of $25 \mu \mathrm{g} / 100 \mathrm{~g}$ body weight (BW) [20]. The $\mathrm{T}_{3}$ was administered by subcutaneous injections, once a day, during the final 2 weeks $[21,22]$. Appropriate volumes of saline were administered, by subcutaneous injections, to the $\mathrm{OB}$ and $\mathrm{C}$ groups. The animals were housed in individual cages under controlled ambient temperature $\left(22-26^{\circ} \mathrm{C}\right)$ and lighting $(12 \mathrm{~h}$ lightdark cycle). Dietary consumption was controlled daily, and weight was assessed weekly. The experimental protocol was approved by the Commission for Ethics in Animal Experimentation at the Botucatu-UNESP School of Medicine, and followed the "Guidelines for the Care and Use of Experimental Animals.”

2.2. Total Body Fat. The total body fat was measured as the sum of epididymal, retroperitoneal, and visceral fat deposits [23]. This data point was utilized to confirm obesity in the animals. In addition, the adiposity index (total body fat divided by final body weight multiplied by 100 , adapted from Boustany et al. [24]) was calculated.
2.3. Biochemical Analysis of Serum. The animals were fasted for 12 to 15 hours, anesthetized with sodium pentobarbital, $50 \mathrm{mg} / \mathrm{kg} / \mathrm{ip}$, and sacrificed by decapitation. The blood was collected in dry tubes and centrifuged at $3000 \mathrm{rpm}$ for 10 minutes. The serum was stored at $-80^{\circ} \mathrm{C}$. Serum concentrations of glucose and triacylglycerol (TG) were assayed using specific kits (CELM, São Paulo, Brazil). Free fatty acids (FFAs) were determined using a commercial kit (WAKO, WAKO Pure Chemical Industries Ltd., Osaka, Japan). Dosing was analyzed by the automated colorimetric enzyme method (Technicon, RA-XT System, Global Medical Instrumentation, Minessota, USA).

2.4. Hormonal Measurements. Serum concentrations of insulin, leptin, resistin, adiponectin, free $T_{3}$, free $T_{4}$, and TSH were measured in all animals. The measurements were performed by immunoassay, measured with a microplate reader (Spectra Max 190-Molecular Devices, Sunnyvale, CA, USA). Commercial kits were utilized for the measurement of leptin, insulin, adiponectin (ELISA kit-Millipore, St. Charles, MO, USA), resistin (ELISA kit-B-Bridge International Inc., Mountain View, CA, USA), and thyroid hormones (ELISA kit-USCN Life Science\&Technology Company, Wuhan, China).

2.5. Gene Expression. Whole RNA was extracted from retroperitoneal adipose tissue using the reagent Trizol (Invitrogen, Sao Paulo, Brazil), according to the manufacturer's instructions. The SuperScript II First-Strand Synthesis System for RT-PCR (Invitrogen, Sao Paulo, Brazil) kit was utilized for the synthesis of $20 \mu \mathrm{L}$ of complementary DNA (cDNA) from $1000 \mathrm{ng}$ of whole RNA. The mRNA levels of leptin (assay Rn 00565158_mL_Applied Biosystems), resistin (assay Rn 00595224_mL_Applied Biosystems), and adiponectin (assay Rn 00595250_mL_Applied Biosystems) were determined by real-time PCR. Quantitative measurements were made with the commercial kit TaqMan qPCR (Applied Biosystems), according to the manufacturer's instructions, in the detection system Applied Biosystems StepOne Plus. Cycling conditions were as follows: enzyme activation at $50^{\circ} \mathrm{C}$ for $2 \mathrm{~min}$, denaturation at $95^{\circ} \mathrm{C}$ for $10 \mathrm{~min}$, the cDNA products were amplified for 40 cycles of denaturation at $95^{\circ} \mathrm{C}$ for $15 \mathrm{~s}$, and annealing/extension at $60^{\circ} \mathrm{C}$ for $1 \mathrm{~min}$. Gene expression was quantified in relation to the values of the $\mathrm{C}$ group after normalization by an internal control (cyclophilin-assay $\mathrm{Rn}$ 00690933_mL-Applied Biosystems) by the method $2^{-\Delta \Delta C T}$, as previously described [25].

2.6. Statistical Analysis. Changes in body weight were evaluated by a confidence interval of $95 \%$. Gene expression, biochemistry, and hormone data were analyzed using analysis of variance (ANOVA) complemented by Bonferroni's test. The data are expressed as mean \pm standard deviation. A 5\% significance level was adopted.

\section{Results}

3.1. Evolution of Body Weight. All the animals had similar BW at the beginning of the study. By week 13, the OB animals 


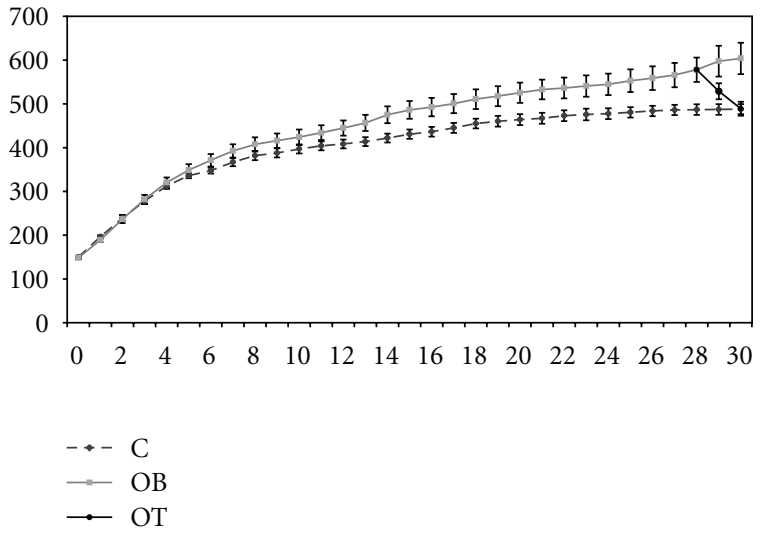

FIGURE 1: Weekly evolution of body weight in the control group (C, $n=10$ ), obese group (OB, $n=10$ ), and obese with $25 \mu \mathrm{g}$ $\mathrm{T}_{3} / 100 \mathrm{~g} \mathrm{BW}(\mathrm{OT}, n=10)$. Data are expressed as means with a $95 \%$ confidence interval.

TABle 1: Composition of body fat: retroperitoneal, epididymal, visceral, and total fat deposits, and adiposity index.

\begin{tabular}{lccc}
\hline Variable & \multicolumn{3}{c}{ Groups } \\
& $\mathrm{C}$ & OB & OT \\
\hline Epid. fat $(\mathrm{g})$ & $8.65 \pm 1.8^{\mathrm{a}}$ & $13.3 \pm 2.6^{\mathrm{b}}$ & $7.0 \pm 1.5^{\mathrm{a}}$ \\
Retro fat $(\mathrm{g})$ & $9.68 \pm 3.2^{\mathrm{a}}$ & $22.1 \pm 6.0^{\mathrm{b}}$ & $9.1 \pm 3.9^{\mathrm{a}}$ \\
Visc. fat $(\mathrm{g})$ & $6.37 \pm 1.5^{\mathrm{a}}$ & $12.9 \pm 4.0^{\mathrm{b}}$ & $5.9 \pm 1.8^{\mathrm{a}}$ \\
Total fat $(\mathrm{g})$ & $24.7 \pm 5.6^{\mathrm{a}}$ & $47.7 \pm 10.8^{\mathrm{b}}$ & $22.0 \pm 6.8^{\mathrm{a}}$ \\
Adipos. I. & $5.06 \pm 1.1^{\mathrm{a}}$ & $7.6 \pm 1.0^{\mathrm{b}}$ & $4.2 \pm 1.4^{\mathrm{a}}$ \\
\hline
\end{tabular}

Epid. Fat: epididymal fat; Retro. Fat: retroperitoneal fat; Visc. Fat: visceral fat; total Fat: total body fat; Adipos. I: adiposity index; C: control; OB: obese; OT: obese with $25 \mu \mathrm{g} \mathrm{T} / 100 \mathrm{gBW}$. Data expressed as mean \pm standard deviation. ANOVA was utilized, complemented by Bonferroni's test. Use of same letters represent $P>0.05$; different letters represent $P<0.05$.

TABLE 2: Biochemical analysis: glucose, triglycerides, and free fatty acids.

\begin{tabular}{lccc}
\hline Variable & \multicolumn{3}{c}{ Groups } \\
& C & OB & OT \\
\hline Glucose $(\mathrm{mg} / \mathrm{dL})$ & $95.0 \pm 5.2^{\mathrm{a}}$ & $93.2 \pm 6.4^{\mathrm{a}}$ & $103.1 \pm 9.7^{\mathrm{b}}$ \\
TG $(\mathrm{mg} / \mathrm{dL})$ & $82.5 \pm 17.8^{\mathrm{a}}$ & $82.2 \pm 15.9^{\mathrm{a}}$ & $73.2 \pm 14.8^{\mathrm{a}}$ \\
FFA $(\mathrm{mmol} / \mathrm{L})$ & $0.51 \pm 0.1^{\mathrm{a}}$ & $0.54 \pm 0.1^{\mathrm{a}}$ & $0.72 \pm 0.1^{\mathrm{b}}$ \\
\hline
\end{tabular}

TG: triglycerides; FFA: free fatty acids; C: control; OB: obese; OT: obese with $25 \mu \mathrm{g} \mathrm{T} / 100 \mathrm{~g}$ BW. Data expressed as mean \pm standard deviation. ANOVA was utilized, complemented by Bonferroni's test. Use of same letters represent $P>0.05$; different letters represent $P<0.05$.

were heavier than the $\mathrm{C}$ group. After 30 weeks of experiment, the $\mathrm{BW}$ of the $\mathrm{OB}$ group $(604 \mathrm{~g} \pm 36 \mathrm{~g})$ was statistically higher than that of the $\mathrm{C}$ group $(488 \mathrm{~g} \pm 11 \mathrm{~g})$. The $\mathrm{BW}$ of the $\mathrm{OB}$ $+\mathrm{T}_{3}$ group $(489 \mathrm{~g} \pm 16 \mathrm{~g})$ was significantly lower than the OB group, but not significantly different from the $\mathrm{C}$ group (Figure 1).

3.2. Total Body Fat. The hypercaloric diet increased fat deposits and the adiposity index. Administration of $\mathrm{T}_{3}$ decreased retroperitoneal, visceral, and epididymal fat deposits.
Similarly, $\mathrm{T}_{3}$ administration decreased total body fat and adiposity index (Table 1).

3.3. Biochemical Analysis. Table 2 presents the values for glucose, TG, and FFA. The hypercaloric diet did not alter the biochemical parameters when compared to the $\mathrm{C}$ group. There was an increase in glucose and FFA levels, but there was no statistical difference in TG levels in the OT group in comparison to the $\mathrm{OB}$ group.

3.4. Hormonal Measurements. The hypercaloric diet did not change the thyroid profile; however, an increase in leptin and resistin levels and a decrease in adiponectin serum concentration was observed. In the OT group, $\mathrm{T}_{3}$ levels were elevated, yet the serum concentrations of free $\mathrm{T}_{4}$ and TSH were diminished (Table 3 ). Administration of $\mathrm{T}_{3}$ reduced the serum levels of adipokines, evaluated leptin (Figure 2(a)), resistin (Figure 2(b)), and adiponectin (Figure 2(c)).

3.5. Gene Expression. Using real-time PCR, gene expression was analyzed using 6 animals per group. The samples were normalized by an internal control (cyclophilin), and the C group was normalized by 1 . The gene expression of leptin (Figure 3(a)) and resistin (Figure 3(b)) was increased in the OB group, but diminished in the OT group. Compared to the $\mathrm{C}$ group, adiponectin gene expression (Figure 3(c)) was decreased by hypercaloric diet. Compared to the OB group, $\mathrm{T}_{3}$ administration decreased adiponectin expression levels.

\section{Discussion}

Obesity is a condition that has reached epidemic levels in recent years [6]. It is a complex disease, where lifestyle interacts with genetic susceptibility to produce the obese phenotype. Nowadays, the substantial rise in obesity indices appears to be due to the lifestyle of the population, particularly due to inappropriate diets and the lack of physical activity [4]. Lifestyle is highly recognized as playing a central role in the etiology of chronic diseases [26]. Furthermore, obesity is associated with several chronic diseases including coronary arterial disease, hypertension, diabetes mellitus type 2, and some forms of cancer [5].

The homogenous behavior of the animals is not assured in experimental studies, even when they are maintained under laboratory conditions. In this context, rats, given normocaloric or hypercaloric rations in models of dietinduced obesity, can present different responses with common characteristics [27]. Thus, classification errors may occur, such that animals submitted to a normocaloric diet can be classified as controls, when in fact they exhibit responses similar to animals that became obese via a hypercaloric diet, or vice versa. For this reason, it becomes necessary to establish a criterion that would enable the separation of animals into control or obese. A study in our laboratory showed that the best indicator of obesity is bodily adiposity, but this index is obtained after the animal is euthanized [27]. However, BW, evaluated in vivo, presents a good correlation with the adiposity index [27]. In this 


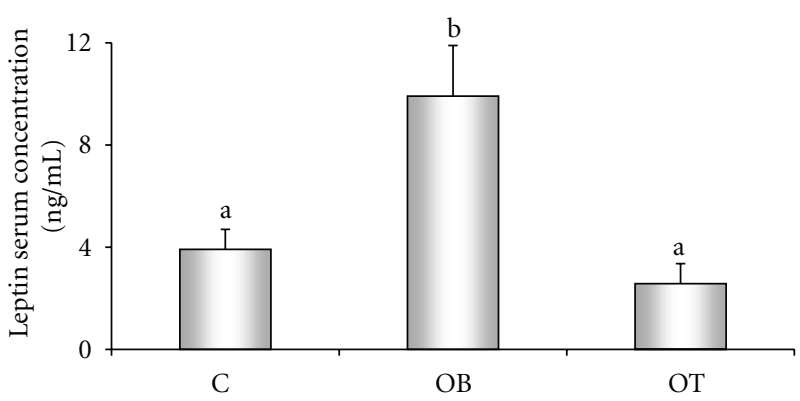

(a)

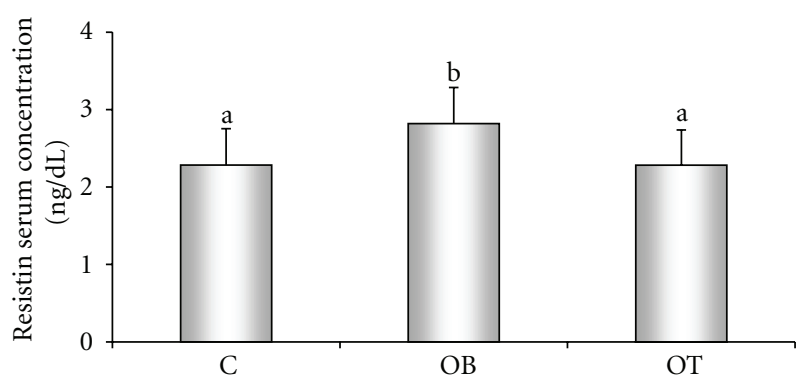

(b)

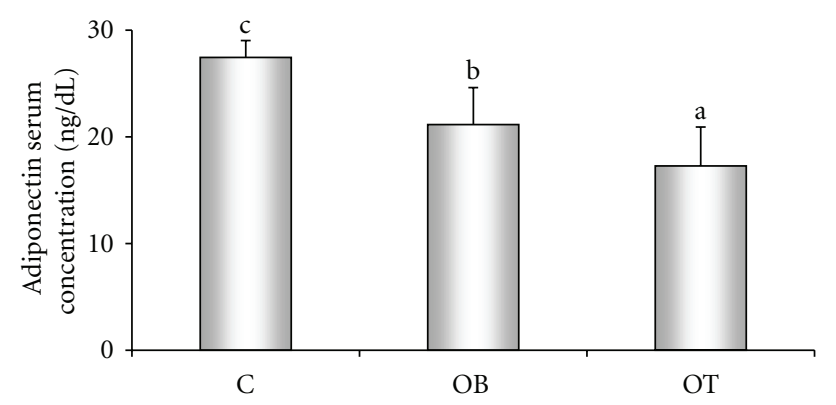

(c)

Figure 2: Influence of different doses of $\mathrm{T}_{3}$ on serum concentration of leptin (a), resistin (b), and adiponectin (c). C: control ( $\left.n=10\right)$; OB: obese $(n=10)$; OT: obese with $25 \mu \mathrm{g} \mathrm{T} / 100 \mathrm{~g} \mathrm{BW}(n=10)$. Data expressed as mean \pm standard deviation. ANOVA was utilized, complemented by Bonferroni's test. Use of same letters represent $P>0.05$; different letters represent $P<0.05$.

context, the control and obese groups were constituted by applying BW as the classification criterion of the study.

Administration of supraphysiological doses of $\mathrm{T}_{3}$ augmented the serum concentration of $\mathrm{T}_{3}$ [28]. In the OT animals, free $\mathrm{T}_{4}$ and TSH levels were diminished compared to $\mathrm{OB}$ animals, not surprisingly as exogenous $\mathrm{T}_{3}$ suppresses the endogenous secretion of TSH and $\mathrm{T}_{4}$ by the thyroid [29], showing the effectiveness of treatment.

Hypercaloric diets induce accentuated weight gain and adiposity. Consumption of diets rich in fat does not augment lipid oxidation in the same proportion, which leads to the elevation of body weight due to the deposition of triacylglycerol in adipose tissue $[30,31]$. The supraphysiological doses of $\mathrm{T}_{3}$ diminished the weight of $\mathrm{OB}$ animals and reduced the adiposity index (Figure 1, Table 1). Hormones and cytokines induce distinct metabolic responses in different fat deposits [32], and this study shows a similar mobilization of all fat deposits in the OT group (Table 1).

Thyroid hormones regulate the metabolism of lipids [33] and that their excess, among other effects, augments lipolysis, the plasmatic concentration of intermediate lipids and lipid peroxidation [34]. Concentrations of free fatty acids are used to indicate the mobilization of fat [35]. In the present study, $\mathrm{T}_{3}$ administration elevates lipolysis in the OT group but did not alter TG levels (Table 2). These data are in agreement with other reports of TG levels not being influenced by thyroid hormone [36].

Excess of thyroid hormones augments plasma glucose levels [37]. The administration of $\mathrm{T}_{3}$ produced a significant diminution of plasma insulin levels in the animals treated
TABLE 3: Hormonal measurement of free triiodothyronine $\left(\mathrm{T}_{3}\right)$, free thyroxine $\left(\mathrm{T}_{4}\right)$, and thyroid-stimulating hormone (TSH).

\begin{tabular}{lccc}
\hline Variable & \multicolumn{3}{c}{ Groups } \\
& $\mathrm{C}$ & OB & OT \\
\hline Free $\mathrm{T}_{3}(\mathrm{pmol} / \mathrm{L})$ & $0.13 \pm 0.06^{\mathrm{a}}$ & $0.12 \pm 0.03^{\mathrm{a}}$ & $0.22 \pm 0.04^{\mathrm{b}}$ \\
Free $\mathrm{T}_{4}(\mathrm{pmol} / \mathrm{L})$ & $45.8 \pm 1.2^{\mathrm{b}}$ & $44.8 \pm 1.2^{\mathrm{b}}$ & $37.8 \pm 1.8^{\mathrm{a}}$ \\
$\mathrm{TSH}(\mathrm{mIU} / \mathrm{L})$ & $13.9 \pm 0.9^{\mathrm{b}}$ & $13.3 \pm 0.8^{\mathrm{b}}$ & $11.0 \pm 1.2^{\mathrm{a}}$ \\
\hline
\end{tabular}

TSH: thyroid stimulating hormone; $\mathrm{T}_{3}$ triiodothyronine; $\mathrm{T}_{4}$ thyroxine; $\mathrm{C}$ : control; OB: obese; OT: obese with $25 \mu \mathrm{g} \mathrm{T} / 100 \mathrm{~g}$ BW. Data expressed as mean \pm standard deviation. ANOVA was utilized, complemented by Bonferroni's test. Use of same letters represent $P>0.05$; different letters represent $P<0.05$.

(data not shown). Nevertheless, the exact influence of thyroid hormones on insulin sensitivity and glucose metabolism remains controversial [38]. However, one important factor to highlight in this study is that the thyroid hormones induce weight loss in a manner related to improving of resistance to insulin (data not shown) [39].

Leptin can influence the interaction between genes and environmental factors. Diets rich in fat raise leptin levels can differentially affect body composition even with similar diets. However, the rise in leptin levels is better explained by increase in body fat [31]. Experimental studies suggest that sensitivity to leptin can be controlled by hormonal and nutritional factors [40]. The literature shows a clear positive correlation between adipose tissue and leptin expression. Diet-induced obesity elevates the gene expression of leptin 


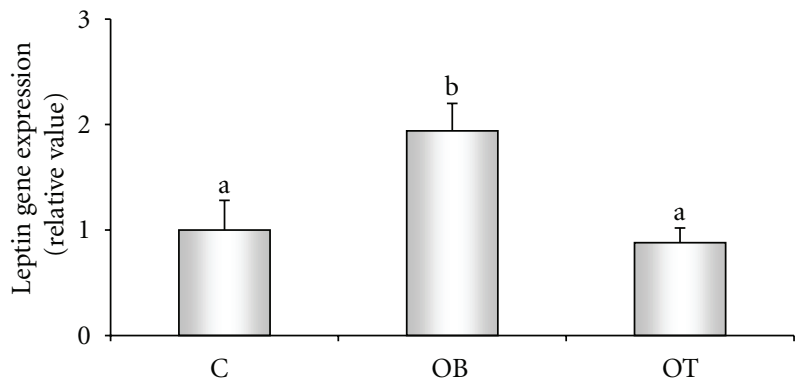

(a)

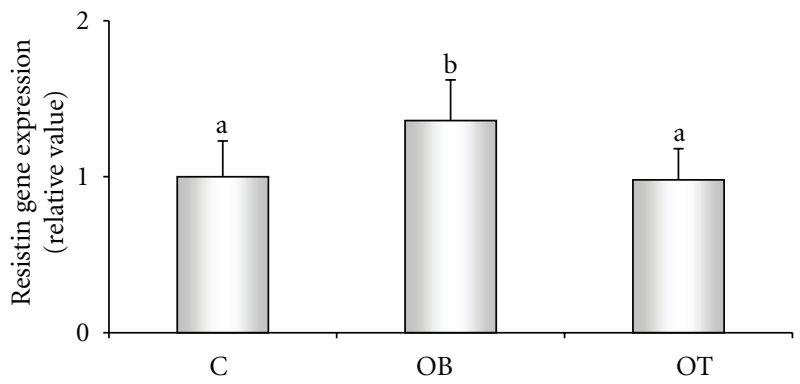

(b)

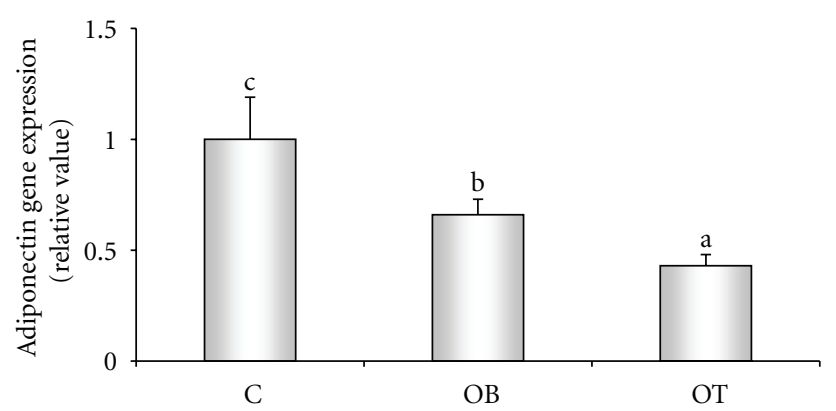

(c)

FIgURE 3: Influence of different $\mathrm{T}_{3}$ doses on the gene expression of leptin (a), resistin (b), and adiponectin (c). C: control ( $n=6$ ); OB: obese $(n=6)$; OT: obese with $25 \mu \mathrm{g} \mathrm{T} / 100 \mathrm{~g} \mathrm{BW}(n=6)$. Data expressed as mean \pm standard deviation. ANOVA was utilized, complemented by Bonferroni's test. Use of same letters represent $P>0.05$; different letters represent $P<0.05$.

$[41,42]$. However, the effects of $\mathrm{T}_{3}$ on the gene expression of leptin present inconsistent results; despite the in vitro data showing that $\mathrm{T}_{3}$ produces a dose-dependent rise in leptin expression [43], our data reveal that, following in vivo hyperthyroidism, leptin gene expression was reduced. In concordance, Pinkney et al. [2] and Zabrocka et al. [28] observed a diminution of leptin expression in response to treatment with $\mathrm{T}_{3}$.

The physiological role of adiponectin has not yet been completely elucidated. Experimental data suggest that adiponectin augments sensitivity to insulin and can present antiatherogenic and antiinflammatory properties [44]. It is well established that adiponectin levels are inversely proportional to the degree of adiposity [45], and weight loss elevates the endogenous production of adiponectin [46]. Here we demonstrate that the $\mathrm{OB}$ group had decreased adiponectin serum levels when compared to the $\mathrm{C}$ group, and the administration of T3, interestingly, even diminishing the body fat mass, presented lower levels of adiponectin (Figures 2(c) and 3(c)). Confirming this data Cabanelas et al. [47] show reduced adiponectin gene expression in inguinal explants of normal rats; also, we have demonstrate, recently that adiponectin levels are decreased in calorie-restricted obese rats [48]. However, in contrast, an experimental study of rats with hyperthyroidism showed an important rise in serum adiponectin [49]. Our data show that supraphysiological $\mathrm{T}_{3}$ doses alter adiponectin expression in obesity, suggesting that $\mathrm{T}_{3}$ causes undesirable effects on adipose tissue.
Resistin prejudices glucose homeostasis and insulin action in mice $[50,51]$. Thus, resistin may perform an intermediary role between obesity and insulin resistance in rodents although this role is still questioned in humans [52]. In this study, a hypercaloric diet increases the serum levels of resistin, while $\mathrm{T}_{3}$ treatment decreases it. The significant diminution of serum resistin in the OT group corroborates the first study performed on humans, in which patients with hyperthyroidism exhibited low serum resistin concentrations [53]. However, these initial findings contrast with subsequent studies that report high resistin levels in hyperthyroidism patients $[54,55]$, showing a divergence in the data. Nevertheless, resistin gene expression is almost undetectable in rats with hyperthyroidism [56]. Our results show that administering supraphysiological doses of $\mathrm{T}_{3}$ decrease resistin expression to the $\mathrm{C}$ group levels (Figure 3(b)).

\section{Conclusion}

The exogenous treatment with $\mathrm{T}_{3}$ is effective in augmenting serum levels of free $\mathrm{T}_{3}$ and diminishing concentrations of free $\mathrm{T}_{4}$ and $\mathrm{TSH}$. Administration of $\mathrm{T}_{3}$ promotes weight loss and decreases adiposity. Following administration of $\mathrm{T}_{3}$, there was a decrease in serum concentration of leptin, resistin, and adiponectin, as well as a reduction in the gene expression. Our data demonstrate that $\mathrm{T}_{3}$ acts, directly or indirectly, on adipose tissue-derived adipokines which can influence whole-body homeostasis. This report provides new 
insights regarding the relationship between $\mathrm{T}_{3}$ and adipokines in obesity model.

\section{Acknowledgments}

The authors thank Sandra Fábio, José Georgete, Mário Bruno, and Sueli Clara for their technical assistance. They are grateful to Dijon HS Campos and Ricardo L Damatto for their contribution in the animals' euthanasia. They also thank FAPESP for the financial support (processes: 06/58177-0 and 07/50041-4). This manuscript has been proofread and edited by native English speakers with related background in BioMed proofreading. All authors declare that there are no conflict of interests.

\section{References}

[1] M. Krotkiewski, "Thyroid hormones in the pathogenesis and treatment of obesity," European Journal of Pharmacology, vol. 440, no. 2-3, pp. 85-98, 2002.

[2] J. H. Pinkney, S. J. Goodrick, J. Katz et al., "Leptin and the pituitary-thyroid axis: a comparative study in lean, obese, hypothyroid and hyperthyroid subjects," Clinical Endocrinology, vol. 49, no. 5, pp. 583-588, 1998.

[3] U. Feldt-Rasmussen, "Thyroid and leptin," Thyroid, vol. 17, no. 5, pp. 413-419, 2007.

[4] T. Reinehr, "Obesity and thyroid function," Molecular and Cellular Endocrinology, vol. 316, no. 2, pp. 165-171, 2010.

[5] S. D. H. Malnick and H. Knobler, "The medical complications of obesity," QJM, vol. 99, no. 9, pp. 565-579, 2006.

[6] World Health Organization, Obesity and Overweight, WHO, Geneva, Switzerland, 2011.

[7] H. Tilg and A. R. Moschen, "Adipocytokines: mediators linking adipose tissue, inflammation and immunity," Nature Reviews Immunology, vol. 6, no. 10, pp. 772-783, 2006.

[8] R. S. Ahima, Y. Qi, N. S. Singhal, M. B. Jackson, and P. E. Scherer, "Brain adipocytokine action and metabolic regulation,” Diabetes, vol. 55, supplemenet 2, pp. S145-S154, 2006.

[9] A. Garg, "Adipose tissue dysfunction in obesity and lipodystrophy," Clinical Cornerstone, vol. 8, supplement 4, pp. S7-S13, 2007.

[10] J. P. Giacobino, "Uncoupling proteins, leptin, and obesity: an updated review," Annals of the New York Academy of Sciences, vol. 967, pp. 398-402, 2002.

[11] K. S. Bell-Anderson and J. M. Bryson, "Leptin as a potencial treatment for obesity," Treatments Endocrinology, vol. 3, pp. 11-18, 2004.

[12] P. G. McTernan, C. L. McTernan, R. Chetty et al., "Increased resistin gene and protein expression in human abdominal adipose tissue," Journal of Clinical Endocrinology and Metabolism, vol. 87, no. 5, pp. 2407-2410, 2002.

[13] D. B. Savage, C. P. Sewter, E. S. Klenk et al., "Resistin / Fizz3 expression in relation to obesity and peroxisome proliferator-activated receptor- $\gamma$ action in humans," Diabetes, vol. 50, no. 10, pp. 2199-2202, 2001.

[14] Y. Deng and P. E. Scherer, "Adipokines as novel biomarkers and regulators of the metabolic syndrome," Annals of the New York Academy of Sciences, vol. 1212, pp. E1-E19, 2010.

[15] U. Meier and A. M. Gressner, "Endocrine regulation of energy metabolism: review of pathobiochemical and clinical chemical aspects of leptin, ghrelin, adiponectin, and resistin," Clinical Chemistry, vol. 50, no. 9, pp. 1511-1525, 2004.
[16] M. Liu and F. Liu, "Transcriptional and post-translational regulation of adiponectin,” Biochemical Journal, vol. 425, no. 1, pp. 41-52, 2009.

[17] F. Vasseur, D. Meyre, and P. Froguel, "Adiponectin, type 2 diabetes and the metabolic syndrome: lessons from human genetic studies," Expert Reviews in Molecular Medicine, vol. 8, no. 27, pp. 1-12, 2006.

[18] J. Vendrell, M. Broch, N. Vilarrasa et al., "Resistin, adiponectin, ghrelin, leptin, and proinflammatory cytokines: relationships in obesity," Obesity Research, vol. 12, no. 6, pp. 962-971, 2004.

[19] A. F. Nascimento, R. A.M. Luvizotto, A. S. Leopoldo et al., "Long-term high-fat diet-induced obesity decreases the cardiac leptin receptor without apparent lipotoxicity," Life Sciences, vol. 88, no. 23-24, pp. 1031-1038, 2011.

[20] G. Giannocco, R. A. Dossantos, and M. T. Nunes, "Thyroid hormone stimulates myoglobin gene expression in rat cardiac muscle," Molecular and Cellular Endocrinology, vol. 226, no. 12, pp. 19-26, 2004.

[21] Y. Minatoya, K. Ito, Y. Kagaya et al., "Depressed contractile reserve and impaired calcium handling of cardiac myocytes from chronically unloaded hearts are ameliorated with the administration of physiological treatment dose of T3 in rats," Acta Physiologica, vol. 189, no. 3, pp. 221-231, 2007.

[22] A. Kokkinos, I. Mourouzis, D. Kyriaki, C. Pantos, N. Katsilambros, and D. V. Cokkinos, "Possible implications of leptin, adiponectin and ghrelin in the regulation of energy homeostasis by thyroid hormone," Endocrine, vol. 32, no. 1, pp. 30-32, 2007.

[23] B. E. Levin and A. A. Dunn-Meynell, "Reduced central leptin sensitivity in rats with diet-induced obesity," American Journal of Physiology, vol. 283, no. 4, pp. R941-R948, 2002.

[24] C. M. Boustany, K. Bharadwaj, A. Daugherty, D. R. Brown, D. C. Randall, and L. A. Cassis, "Activation of the systemic and adipose renin-angiotensin system in rats with diet-induced obesity and hypertension," American Journal of Physiology, vol. 287, no. 4, pp. R943-R949, 2004.

[25] K. J. Livak and T. D. Schmittgen, "Analysis of relative gene expression data using real-time quantitative PCR and the 2$\Delta \Delta$ CT method," Methods, vol. 25, no. 4, pp. 402-408, 2001.

[26] F. W. Booth, S. E. Gordon, C. J. Carlson, and M. T. Hamilton, "Waging war on modern chronic diseases: primary prevention through exercise biology," Journal of Applied Physiology, vol. 88, no. 2, pp. 774-787, 2000.

[27] A. F. Nascimento, M. M. Sugizaki, A. S. Leopoldo et al., "Misclassification probability as obese or lean in hypercaloric and normocaloric diet," Biological Research, vol. 41, no. 3, pp. 253-259, 2008.

[28] L. Zabrocka, J. Klimek, and J. Swierczynski, "Evidence that triiodothyronine decreases rat serum leptin concentration by down-regulation of leptin gene expression in white adipose tissue," Life Sciences, vol. 79, no. 11, pp. 1114-1120, 2006.

[29] E. D. Abel, E. G. Moura, R. S. Ahima et al., "Dominant inhibition of thyroid hormone action selectively in the pituitary of thyroid hormone-receptor- $\beta$ null mice abolishes the regulation of thyrotropin by thyroid hormone," Molecular Endocrinology, vol. 17, no. 9, pp. 1767-1776, 2003.

[30] N. Tentolouris, S. Pavlatos, A. Kokkinos, D. Perrea, S. Pagoni, and N. Katsilambros, "Diet-induced thermogenesis and substrate oxidation are not different between lean and obese women after two different isocaloric meals, one rich in protein and one rich in fat," Metabolism, vol. 57, no. 3, pp. 313-320, 2008. 
[31] P. Schrauwen and K. R. Westerterp, "The role of high-fat diets and physical activity in the regulation of body weight," British Journal of Nutrition, vol. 84, no. 4, pp. 417-427, 2000.

[32] C. M. Pond, "Physiological specialisation of adipose tissue," Progress in Lipid Research, vol. 38, no. 3, pp. 225-248, 1999.

[33] L. H. Duntas, "Thyroid disease and lipids," Thyroid, vol. 12, no. 4, pp. 287-293, 2002.

[34] A. L. D. Riis, C. H. Gravholt, C. B. Djurhuus, H. Norrelund, J. O. Jorgensen, J. Weeke et al., "Elevated regional lipolysis in hyperthyroidism," Journal of Clinical Endocrinology \& Metabolism, vol. 87, no. 10, pp. 4747-4753, 2002.

[35] J. H. Holmes and L. J. Lambourne, "The relation between plasma free fatty acid concentration and the digestible energy intake of cattle," Research in Veterinary Science, vol. 11, no. 1, pp. 27-36, 1970.

[36] A. W. C. Kung, R. W. C. Pang, I. Lauder, K. S. L. Lam, and E. D. Janus, "Changes in serum lipoprotein(a) and lipids during treatment of hyperthyroidism," Clinical Chemistry, vol. 41, no. 2, pp. 226-231, 1995.

[37] G. D. Dimitriadis and S. A. Raptis, "Thyroid hormone excess and glucose intolerance," Experimental and Clinical Endocrinology and Diabetes, vol. 109, supplement 2, pp. S225S239, 2001.

[38] S. Setia, M. G. Sridhar, B. C. Koner, Z. Bobby, V. Bhat, and L. Chaturvedula, "Increased insulin sensitivity in intrauterine growth retarded newborns-do thyroid hormones play a role?" Clinica Chimica Acta, vol. 376, no. 1-2, pp. 37-40, 2007.

[39] T. Reinehr, W. Kiess, T. Kapellen, and W. Andler, "Insulin sensitivity among obese children and adolescents, according to degree of weight loss," Pediatrics, vol. 114, no. 6, pp. 1569$1573,2004$.

[40] P. A. Bennett, K. Lindell, C. Karlsson, I. C. A. F. Robinson, L. M. S. Carlsson, and B. Carlsson, "Differential expression and regulation of leptin receptor isoforms in the rat brain: effects of fasting and oestrogen," Neuroendocrinology, vol. 67, no. 1, pp. 29-36, 1998.

[41] S. O. Kim, S. J. Yun, B. Jung et al., "Hypolipidemic effects of crude extract of adlay seed (Coix lachrymajobi var. mayuen) in obesity rat fed high fat diet:Relations of TNF- $\alpha$ and leptin mRNA expressions and serum lipid levels," Life Sciences, vol. 75, no. 11, pp. 1391-1404, 2004.

[42] M. Y. Wang, L. Orci, M. Ravazzola, and R. H. Unger, "Fat storage in adipocytes requires inactivation of leptin's paracrine activity: implications for treatment of human obesity," Proceedings of the National Academy of Sciences of the United States of America, vol. 102, no. 50, pp. 18011-18016, 2005.

[43] T. Yoshida, T. Monkawa, M. Hayashi, and T. Saruta, "Regulation of expression of leptin mRNA and secretion of leptin by thyroid hormone in 3T3-L1 adipocytes," Biochemical and Biophysical Research Communications, vol. 232, no. 3, pp. 822 826, 1997.

[44] B. J. Goldstein and R. Scalia, "Adipokines and vascular disease in diabetes," Current Diabetes Reports, vol. 7, no. 1, pp. 25-33, 2007.

[45] C. Weyer, T. Funahashi, S. Tanaka et al., "Hypoadiponectinemia in obesity and type 2 diabetes: close association with insulin resistance and hyperinsulinemia," Journal of Clinical Endocrinology and Metabolism, vol. 86, no. 5, pp. 1930-1935, 2001.

[46] J. M. Moreno-Navarrete, V. Cataln, F. Ortega et al., "Circulating omentin concentration increases after weight loss," Nutrition and Metabolism, vol. 7, article 27, 2010.

[47] A. Cabanelas, A. Cordeiro, N. A. D. Santos Almeida et al., "Effect of triiodothyronine on adiponectin expression and leptin release by white adipose tissue of normal rats," Hormone and Metabolic Research, vol. 42, no. 4, pp. 254-260, 2010.

[48] R. A. M. Luvizotto, M. T. Síbio, R. M. C. Olímpio et al., "Supraphysiological triiodothyronine doses diminish leptin and adiponectin gene expression, but do not alter resistin expression in calorie restricted obese rats," Hormone and Metabolic Research, vol. 43, no. 7, pp. 452-457, 2011.

[49] C. N. Aragão, L. L. Souza, A. Cabanelas, K. J. Oliveira, and C. C. Pazos-Moura, "Effect of experimental hypo- and hyperthyroidism on serum adiponectin," Metabolism, vol. 56, no. 1, pp. 6-11, 2007.

[50] C. M. Steppan and M. A. Lazar, "The current biology of resistin," Journal of Internal Medicine, vol. 255, no. 4, pp. 439447, 2004.

[51] M. Nakata, T. Okada, K. Ozawa, and T. Yada, "Resistin induces insulin resistance in pancreatic islets to impair glucoseinduced insulin release," Biochemical and Biophysical Research Communications, vol. 353, no. 4, pp. 1046-1051, 2007.

[52] S. Bo, R. Gambino, A. Pagani et al., "Relationships between human serum resistin, inflammatory markers and insulin resistance," International Journal of Obesity, vol. 29, no. 11, pp. 1315-1320, 2005.

[53] P. Iglesias, P. Alvarez Fidalgo, R. Codoceo, and J. J. Díez, "Serum concentrations of adipocytokines in patients with hyperthyroidism and hypothyroidism before and after control of thyroid function," Clinical Endocrinology, vol. 59, no. 5, pp. 621-629, 2003.

[54] G. E. Krassas, N. Pontikides, K. Loustis, G. Koliakos, T. Constantinidis, and D. Panidis, "Resistin levels in hyperthyroid patients before and after restoration of thyroid function: relationship with body weight and body composition," European Journal of Endocrinology, vol. 153, no. 2, pp. 217-221, 2005.

[55] S. Yaturu, S. Prado, and S. R. Grimes, "Changes in adipocyte hormones leptin, resistin, and adiponectin in thyroid dysfunction," Journal of Cellular Biochemistry, vol. 93, no. 3, pp. 491496, 2004.

[56] R. Nogueiras, O. Gualillo, J. E. Caminos, F. F. Casanueva, and C. Diéguez, "Regulation of resistin by gonadal, thyroid hormone, and nutritional status," Obesity Research, vol. 11, no. 3, pp. 408-414, 2003. 


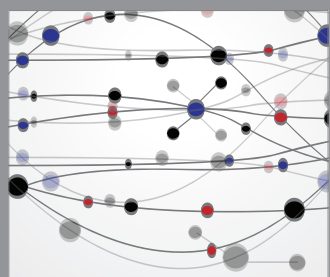

The Scientific World Journal
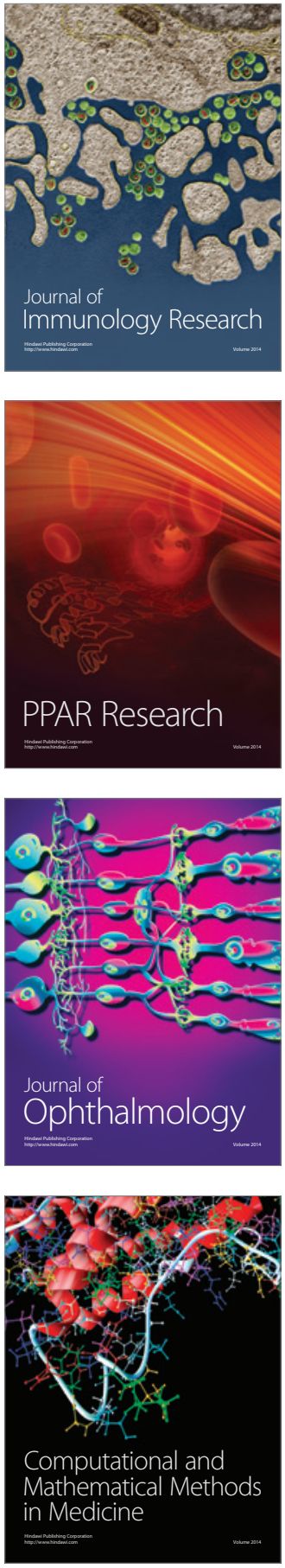

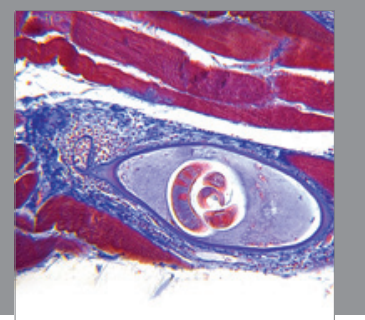

Gastroenterology

Research and Practice
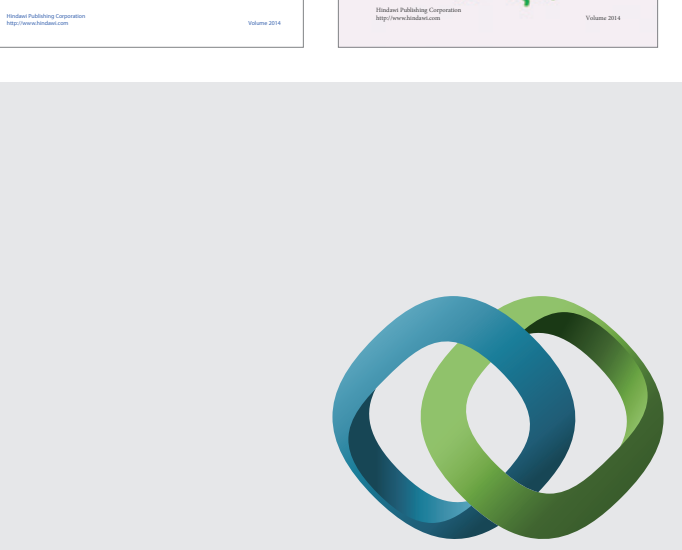

\section{Hindawi}

Submit your manuscripts at

http://www.hindawi.com
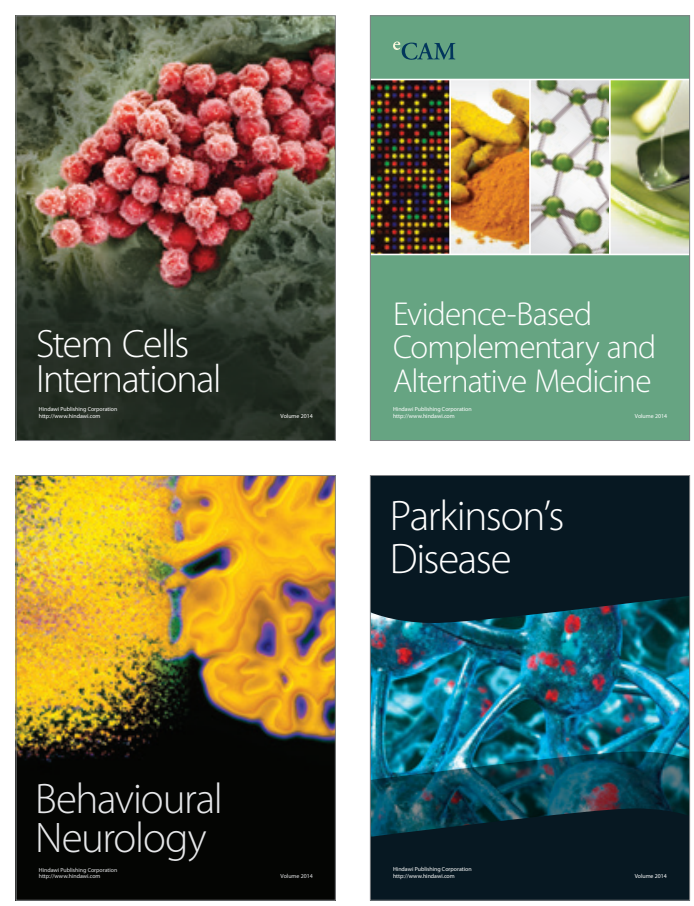

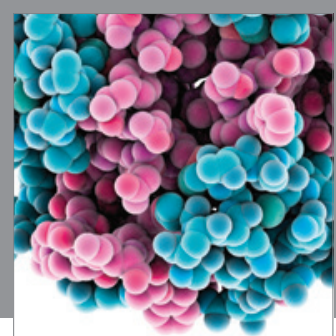

Journal of
Diabetes Research

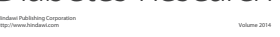

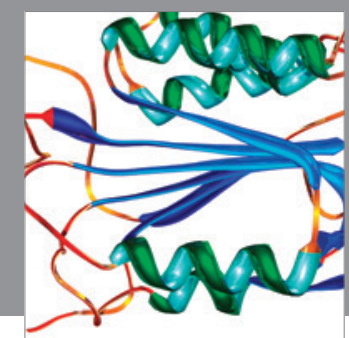

Disease Markers
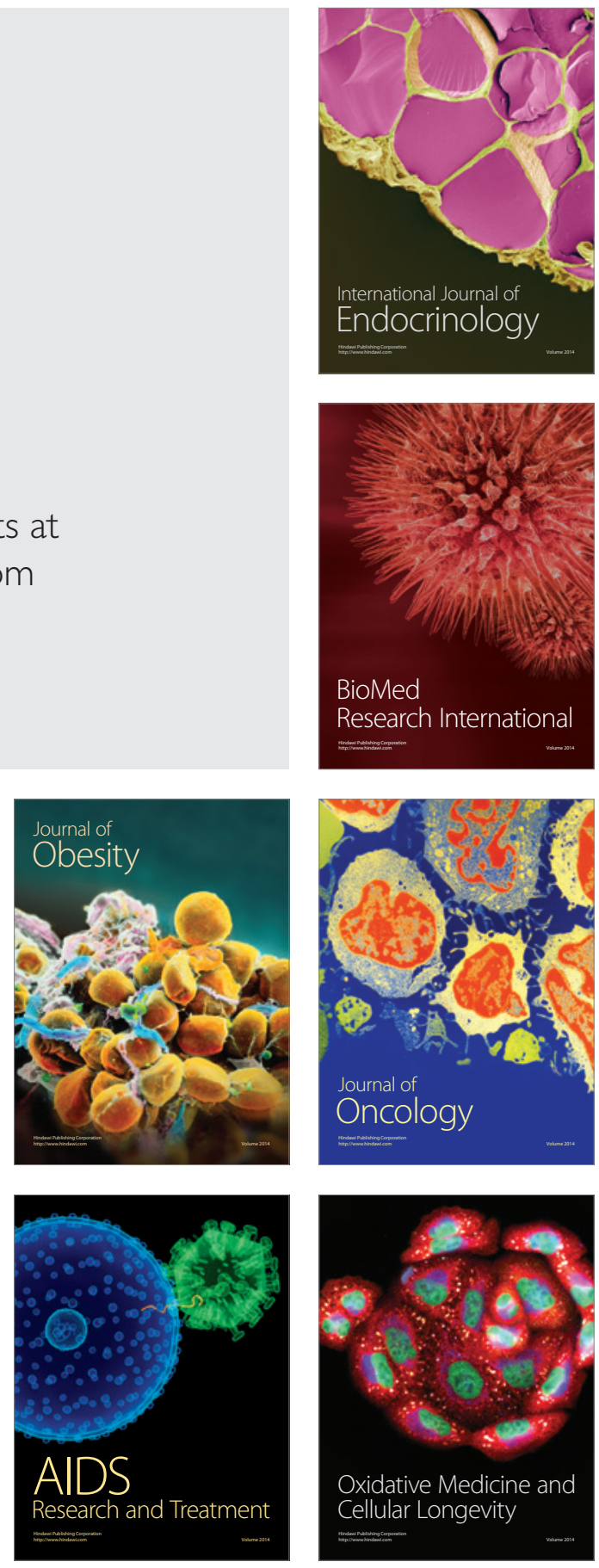